\title{
THE OXFORD HANDBOOK OF
}

\section{THE}

\section{ARCHAEOLOGY}

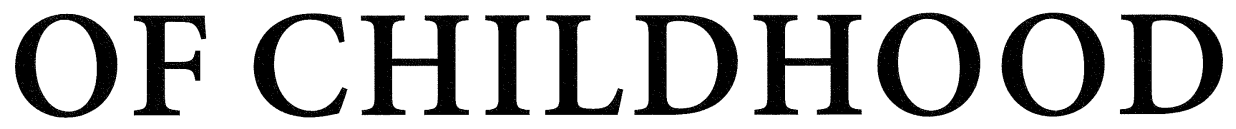

Edited by

SALLY CRAWFORD, DAWN M. HADLEY,

and

\section{GILLIAN SHEPHERD}
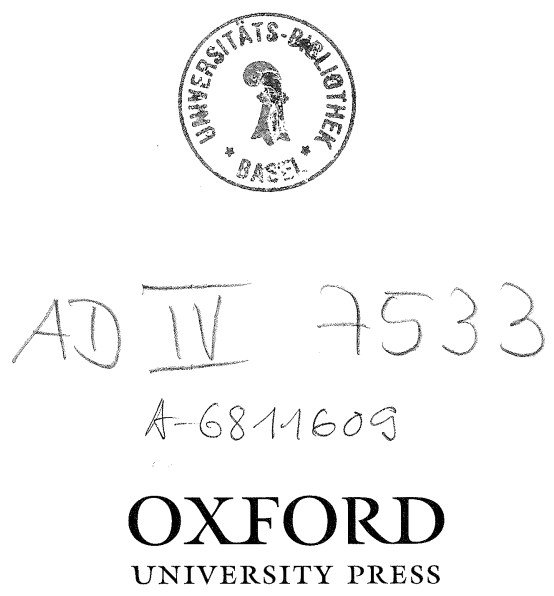

https://www.oxfordhandbooks.com/view/10.1093/oxfordhb/9780199670697.001.0001/ oxfordhb-9780199670697-e-7 


\section{OXFORD \\ UNIVERSITY PRESS}

\section{Great Clarendon Street, Oxford, ox2 6DP, \\ United Kingdom}

Oxford University Press is a department of the University of Oxford. It furthers the University's objective of excellence in research, scholarship, and education by publishing worldwide. Oxford is a registered trade mark of Oxford University Press in the UK and in certain other countries

$$
\text { (C) Oxford University Press } 2018
$$

The moral rights of the authors have been asserted

\section{First Edition published in 2018}

Impression: 1

All rights reserved. No part of this publication may be reproduced, stored in a retrieval system, or transmitted, in any form or by any means, without the prior permission in writing of Oxford University Press, or as expressly permitted by law, by licence or under terms agreed with the appropriate reprographics rights organization. Enquiries concerning reproduction outside the scope of the above should be sent to the Rights Department, Oxford University Press, at the address above

You must not circulate this work in any other form and you must impose this same condition on any acquirer

Published in the United States of America by Oxford University Press 198 Madison Avenue, New York, NY 10016, United States of America

$$
\begin{gathered}
\text { British Library Cataloguing in Publication Data } \\
\text { Data available } \\
\text { Library of Congress Control Number: } 2018940968 \\
\text { ISBN 978-0-19-967069-7 } \\
\text { Printed and bound by } \\
\text { CPI Group (UK) Ltd, Croydon, CRo 4YY }
\end{gathered}
$$

Links to third party websites are provided by Oxford in good faith and for information only. Oxford disclaims any responsibility for the materials contained in any third party website referenced in this work. 


\section{CONTENTS}

List of Figures

xi

List of Tables

xxi

List of Abbreviations

xxiii

List of Contributors

$\mathrm{xxV}$

\section{SECTION I INTRODUCTIONS: THE HISTORY AND IMPACT OF THE ARCHAEOLOGY OF CHILDHOOD}

1. The Archaeology of Childhood: The Birth and Development of a Discipline

Sally Crawford, Dawn M. Hadley, and Gillian Shepherd

2. The History of the Archaeology of Childhood 38

Grete Lillehammer

\section{SECTION II DEFINING CHILDREN AND CHILDHOOD}

3. Techniques for Identifying the Age and Sex of Children at Death

JO BUCKBERRY

4. The Study of Growth in Skeletal Populations

Simon MaYs

5. Cultural Models of Stages in the Life Course

M. Annette Grove and David F. Lancy

6. Infants and Mothers: Linked Lives and

Embodied Life Courses

REBECCA GOWLAND 


\section{SECTION III CHILDREN, FAMILY, AND HOUSEHOLDS}

7. Prehistoric Households and Childhood: Growing Up in a Daily Routine

BRIGITTE RÖDER

8. Archaeological and Epigraphic Evidence for Infancy

in the Roman World

Maureen Carroll

9. Roman Household Organization

Penelope Allison

10. Material Culture and Childhood in Harappan South Asia

SUPRIYA VARMA

11. Working-class Childhood in Nineteenth-century

New York City

Rebecca Yamin

\section{SECTION IV LEARNING, SOCIALIZATION, AND TRAINING}

12. Learning the Tools of Survival in the Thule and Dorset

Cultures of Arctic Canada

Robert W. PArk

13. Educating Victorian Children: A Material Culture

Perspective from Cambridge, England

Craig Cessford

14. Above and Below the Surface: Environment, Work, Death, and

Upbringing in Sixteenth- to Seventeenth-century Sweden

Anne IngVarsson, Jan Mispelaere, and Ylva Bäckström

15. Boys at Sea: An Osteological and Historical

Analysis of Ships' Boys in the Late Eighteenth- to

Early Nineteenth-century British Royal Navy

Ceridwen Boston

16. Training Children for Work in the Nineteenth

Century: Material Culture Approaches

Vicky Crewe 


\section{SECTION V SELF, IDENTITY, AND COMMUNITY}

17. Portrait of a Palaeolithic Family: Art, Ornamentation, and Children's Relationship with their Community

Jessica Cooney Williams

18. Care and Socialization of Children in the European

Bronze Age

338

Margarita Sánchez Romero

19. Representations of Children in Ancient Greece

352

Olympia Bobou

20. Children's Graffiti in Roman Pompeii and Herculaneum

376

Katherine V. Huntley

21. Vecino Archaeology and the Politics of Play

in New Mexico, USA

B. SUNDAY EISELT

22. Children and Migration

404

DAWN M. HADLEY

\section{SECTION VI HEALTH, DISEASE, AND ENVIRONMENT}

23. The Developing Forager: Reconstructing Childhood Activity

Patterns from Long Bone Cross-sectional Geometry

429

LESLEy HaRrington AND BenJamin Osipov

24. Feeding Infants from the Iron Age to the Early

Medieval Period in Britain

RebeCCA C. ReDFERN

25. Disease and Trauma in the Children from Roman Britain

MARY E. LeWIS

26. Infant Head Shaping in Eurasia in the First Millennium AD

Susanne Hakenbeck

27. The Contribution of Stable Isotope Analysis to the Study of

Childhood Movement and Migration

Katie A. Hemer and Jane A. Evans 


\section{SECTION VII DEATH, MEMORY, AND MEANING}

28. Where Are the Children? Locating Children in Funerary Space in the Ancient Greek World

GILLIAN SHEPHERD

29. A World Without Play? Children in Ancient Egyptian Art and Iconography

NiCOLA HARRINGTON

30. Roman Sarcophagi and Children

JANET HuSKInSON

31. Child Sacrifice in the Ancient Andes: Power and Sociopolitical Dynamics in Antiquity

Deborah E. Blom

32. Adult Appearances? The Representation of Children and Childhood in Medieval Art

SOPHIE OOSTERWIJK

33. Children's Burial Grounds (cillíní) in Ireland: New Insights into an Early Modern Religious Tradition 608 Colm J. Donnelly and Eileen M. Murphy

\section{SECTION VIII SEEING, PRESENTING, AND INTERPRETING THE ARCHAEOLOGY OF CHILDHOOD}

34. Gazing on the Past (and Being Photobombed by Children): Archaeology, the Early Years of Modern Photography, and the Visible/Invisible Child

Sally Crawford and Katharina Ulmschneider

35. From the Archaeology of Childhood to Modern Children Visiting Archaeological Museums: An Italian Perspective 
36. Material Culture, Museums, Movies, and Make Believe: Representing Medieval Childhood 668 Mark A. HALL

37. Presenting Children from the Distant Past in Museums 687 Sharon BrookshaW

Author Index 701

Subject Index 


\title{
PREHISTORICHOUSEHOLDS \\ AND CHILDHOOD
}

\author{
Growing Up in a Daily Routine
}

\section{BRIGITTE RÖDER}

'HouseHolD' and 'childhood' are two ideologically and emotionally highly charged cultural concepts that are intrinsically intertwined with other basic concepts of contemporary Western society, such as 'house, 'home', and 'family': 'For many people the house is synonymous with home ... The word "home" ... may be filled with emotional meaning-reminders of childhood and the roots of our being, or concepts of privacy, freedom and security' (Parker-Pearson and Richards 1994: 5). The terms 'household' and 'childhood' invoke a whole raft of ideas and notions, which are fundamentally influenced by societal ideals of intact childhood and family life, by personal everyday life experiences, and by memories of one's own childhood that are potentially nostalgically biased. The fact that we all had a childhood and grew up and still live in a household of some description supports the assumption that these fundamental experiences are universal and that 'household' and 'childhood' are self-evident categories.

These personal, everyday, and biographical experiences and certainties are in opposition to the findings of the humanities, which demonstrate that 'household' and 'childhood, rather than constituting universal categories, are cultural concepts that depend on various factors. Contemporary Western ideas of childhood and household hark back to eighteenth- and nineteenth-century bourgeois society that developed new concepts of family and of the relationships between the genders and generations. As part of this reorganization of the central societal institutions and constitutively linked with the bourgeois family model, very specific cultural concepts of 'household' and 'childhood' were defined. Despite all the historical and social changes that have taken place in the meantime, the concepts of bourgeois society still have a fundamental impact on our society-either as an ideal model or as a bugbear. Consequently, they also play a part in the cultural preconceptions of archaeologists and can enter their research unnoticed by way of implicit assumptions. 
The fact that bourgeois society has declared that the social institutions and concepts it created-such as its family model (and thus the concept of household, which is intrinsically linked with it) and its notion of childhood-are 'natural' and 'universal', and above all 'primordial', makes it all the more important to reflect on these cultural preconceptions. The strategy of legitimizing new social constructs by naturalizing and archaizing them, thus declaring them to be 'natural facts', has proved highly efficient to this day, not only in social debates but also within academic discourse. This may explain why many archaeological publications and images present bourgeois society as an implied analogous model and why prehistory is depicted as a kind of theme park of bourgeois society (Röder 2013), despite the fact that gender, childhood, and household archaeologists in particular have fundamentally criticized these 'nineteenth-century bourgeois premises' (Leach 1999: 195) being projected onto the past and have identified them as an epistemological trap (Spencer-Wood 1999: 162-6; Panter-Brick 2000: 4-9; Robin 2002: 246-8; Kamp 2006: 119; Thomas 2006: 42; Brumfiel and Robin 2008: 2).

A number of contemporary Western notions and ideals that hark back to nineteenthcentury bourgeois concepts are of particular importance for the study of households and childhood: childhood is seen as a natural, biological, and universal period of life (Schwartzman 2006: 125). On one hand devalued as a 'still immature status of preparation to adult life' (Liebel 2004: 77), it is at the same time romanticized and idealized. It appears as some kind of 'reservation' where 'nothing serious' happens but where no 'utilizable' results can be achieved either (Liebel 2004: 178). In this concept, children live in a 'walled garden': 'The walled garden represents an idealized world, free of oppression and exploitation-a world that numerous studies have shown does not exist for most children' (Hobbs, McKechnie, and Lavalette 1999: 212). The notion that children must be kept in a protected space and shielded from all the hardships of life, however, has a paternalistic downside and illustrates just how few competences children are given credit for: 'The metaphor also implies a barrier to the outside world where children, because they are children, are denied access to activities that adults take for granted. The fact of biological immaturity is utilized to determine a presumed social, political, and economic incompetence, as a result of which children find themselves excluded from decision-making at all levels of society' (Hobbs, McKechnie, and Lavalette 1999: 212; also Liebel 2004: 178). This attitude results in children being excluded not only from decision-making but-provided the economic situation allows it-also from taking on responsibilities and carrying out economic activities, thus rendering them completely dependent on adults.

The family is viewed as the ideal space for growing up because this is the only wayin people's perception-that a protected and sheltered childhood is possible, which is viewed first and foremost as a period of play and learning. In spite of the current move towards more pluralized forms of relationships and families, the bourgeois family model still has the status of a guiding concept of society. 'Family' is thus primarily defined as a nuclear family, which consists of a monogamous heterosexual couple and their joint children, and where the man takes on the role of provider while the woman assumes the role of spouse, housewife, and mother. The members of such a family are 
The fact that bourgeois society has declared that the social institutions and concepts it created-such as its family model (and thus the concept of household, which is intrinsically linked with it) and its notion of childhood-are 'natural' and 'universal', and above all 'primordial', makes it all the more important to reflect on these cultural preconceptions. The strategy of legitimizing new social constructs by naturalizing and archaizing them, thus declaring them to be 'natural facts', has proved highly efficient to this day, not only in social debates but also within academic discourse. This may explain why many archaeological publications and images present bourgeois society as an implied analogous model and why prehistory is depicted as a kind of theme park of bourgeois society (Röder 2013), despite the fact that gender, childhood, and household archaeologists in particular have fundamentally criticized these 'nineteenth-century bourgeois premises' (Leach 1999: 195) being projected onto the past and have identified them as an epistemological trap (Spencer-Wood 1999: 162-6; Panter-Brick 2000: 4-9; Robin 2002: 246-8; Kamp 2006: 119; Thomas 2006: 42; Brumfiel and Robin 2008: 2).

A number of contemporary Western notions and ideals that hark back to nineteenthcentury bourgeois concepts are of particular importance for the study of households and childhood: childhood is seen as a natural, biological, and universal period of life (Schwartzman 2006: 125). On one hand devalued as a 'still immature status of preparation to adult life' (Liebel 2004: 77), it is at the same time romanticized and idealized. It appears as some kind of 'reservation' where 'nothing serious' happens but where no 'utilizable' results can be achieved either (Liebel 2004: 178). In this concept, children live in a 'walled garden': 'The walled garden represents an idealized world, free of oppression and exploitation - a world that numerous studies have shown does not exist for most children' (Hobbs, McKechnie, and Lavalette 1999: 212). The notion that children must be kept in a protected space and shielded from all the hardships of life, however, has a paternalistic downside and illustrates just how few competences children are given credit for: 'The metaphor also implies a barrier to the outside world where children, because they are children, are denied access to activities that adults take for granted. The fact of biological immaturity is utilized to determine a presumed social, political, and economic incompetence, as a result of which children find themselves excluded from decision-making at all levels of society' (Hobbs, McKechnie, and Lavalette 1999: 212; also Liebel 2004: 178). This attitude results in children being excluded not only from decision-making but-provided the economic situation allows it-also from taking on responsibilities and carrying out economic activities, thus rendering them completely dependent on adults.

The family is viewed as the ideal space for growing up because this is the only wayin people's perception-that a protected and sheltered childhood is possible, which is viewed first and foremost as a period of play and learning. In spite of the current move towards more pluralized forms of relationships and families, the bourgeois family model still has the status of a guiding concept of society. 'Family' is thus primarily defined as a nuclear family, which consists of a monogamous heterosexual couple and their joint children, and where the man takes on the role of provider while the woman assumes the role of spouse, housewife, and mother. The members of such a family are 
linked by close emotional bonds, so-called family love, and they share a permanent domicile which, in contrast to the 'public outside', is perceived as a 'protected private area.' They run a joint household which to the outside world portrays an autonomous economic unit and within the family is based on altruistic principles-i.e. the resources generated by the father or the parents are fed into a joint pool and are eventually handed down to the children. The familial relationships-and thus the household-are characterized by an extraordinarily high stability. Any changes that might occur are largely of a demographic nature: the household is expanded by children being born, whilst family members dying or children marrying and moving out to start their own household cause it to contract. The intake of new family members happens only in exceptional cases and mainly concerns relations in need of care or elderly relatives living on their own. Because 'family' and 'household' coincide, this family model also determines the characteristics of the household, e.g. its members, their roles, the division of labour, and the household's stability.

So much for the contemporary cultural concepts which, while developed in the eighteenth and nineteenth centuries, still fundamentally shape Western society's understanding of a 'normal childhood', a 'normal family', and a 'normal household'. The fact that these nineteenth-century bourgeois concepts became hegemonic for society as a whole, although most people lived within completely different everyday realities, is a remarkable phenomenon indeed. ${ }^{1}$ Even more remarkable, however, is their persistence, which seems to defy all the social changes around childhood, family, and households. This persistence is also supported by prehistoric archaeologists who reproduce the cultural concepts of bourgeois society in their studies and continuously reactualize the strategy of legitimizing the notion that this represents the 'primordial' and 'natural' types of societal coexistence which can be presumed to have existed universally 'since time immemorial'. The subject matter 'prehistoric households and childhood' challenges us very specifically to reflect upon these cultural concepts and 'to open space for alternative voices and new means of discourse' (Lawrence 1999: 122).

\section{Childhood as AN ANALYTiCAL CATEgory}

'Childhood' on one hand is a period of biological growth, rapid psychosocial maturation, and intensive learning. On the other hand, it is also a social category that varies both cross-culturally and within cultures. Therefore, childhood is also a scientific analytical category. As Chris Jenks (1996: 121-2) put it: 'Sociological and anthropological research has now sharpened a theoretical focus on the plurality of childhoods, a plurality evidenced not only cross-culturally but also within cultures ... the experience of childhood is fragmented and stratified, by class, age, gender, and ethnicity, by urban or rural locations and by particularized identities cast for children through disability or ill health. The factors that, according to Jenks, characterize present-day childhoods, much like the variability between and within cultures, can also be presumed to have existed in 
prehistoric times, so that we must always assume that a variety of childhoods existed in the past.

However, which years make up a person's 'childhood', or in other words, what is a 'child'? Kathryn Kamp (2006: 116) pointed out that we must differentiate between 'childhood' as a culturally defined stage in a person's life cycle and the individual or collective experiences of 'children.' 'Children' are not a universal category, no more than 'women' or 'men'. Whilst all societies differentiate between adult and subadult persons, there is huge disparity between different cultural groups with regard to the actual ages at which such boundaries are defined and the personality traits, roles, tasks, rights, etc. that are attributed to each stage of life. By attempting not to limit one's archaeological research to the biological dimension of age, i.e. to anthropological age categories in order to project the current categories of 'children', 'adolescents', and 'adults' onto prehistoric reality, it becomes quite a challenge to define these allegedly self-evident terms: once age is also perceived as a social criterion, the category 'child' disintegrates into a cultural variety of options. Due to the great impact of a baby or infant's existential dependency and need for protection, early childhood (up to around three years of age) is the only stage that appears to be a constant which is culturally largely independent (Hug 2007, 2008: 856). ${ }^{2}$ It is much less variable than the circumstances of older children, both with regard to its duration and its cultural characteristics (see Grove and Lancy, Chapter 5 of this volume).

Clues for the emic formation of age structures or life cycle concepts with regard to prehistoric societies are provided at best by studies of grave goods in conjunction with anthropological age determinations (Sofaer Derevenski 200oa; Stoodley 2000). Such studies, however, are still quite rarely carried out. This means that in studying 'prehistoric households and childhood' it must remain largely open which age groups are actually being analysed in each individual case. As will be outlined later, social anthropological studies have shown that we may work on the basic assumption that prehistoric young people, in contrast to most children and adolescents in modern Western societies, were probably integrated into the everyday cycle of domestic activities from a very young age, ${ }^{3}$ possibly even between the ages of three and five years. However, here too, we must assume that there were various types of childhood: the children of an Iron Age elite family were probably less involved in everyday chores or participated in different activities than the children of their servants, although they may have been part of the same household (Figure 7.1).

\section{HOUSEHOLD ARCHAEOLOGY: THE DISCOVERY OF EVERYDAY LIFE}

Household archaeology stands for the discovery of everyday life, and for an interest in the daily routines that, while unspectacular, shape the mode of existence of both the 


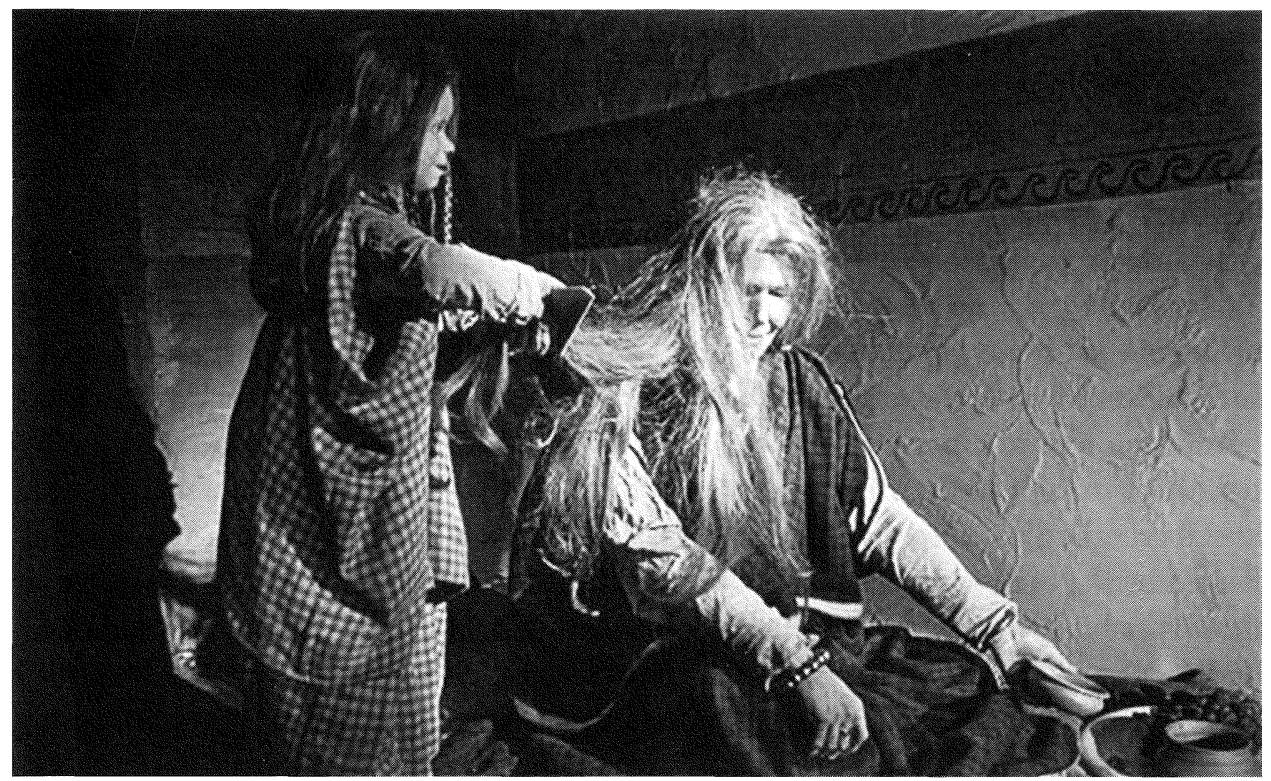

FIGURE 7.1 A young servant combing her mistress's hair. This scene points out that there were various types of childhood. The children of an Iron Age elite family were probably less involved in everyday chores or participated in different activities from the children of their servants, although they may have been part of the same household. Reproduced by permission of the Kantonales Museum für Urgeschichte(n) Zug (Switzerland.)

individual and the cultural group or society. Starting in the 1970s and 1980s, ${ }^{4}$ this new research field began to contrast the 'macrocosm archaeological culture' with the 'microcosm household' as a unit of analysis, thereby developing theoretical and methodological lines of approach to research this 'microcosm'. The household was defined as 'the next bigger thing on the social map after an individual' (Hammel 1984:40-1) and seen as 'the primary unit within the socioeconomic structure' (Steadman 1996: 55). The notion that households were the 'minimal social unit' (Briz i Godino et al. 2013: 24) upon which village communities and finally archaeological cultures were based, harks back to the Western bourgeois concept, according to which the (nuclear) family, which was equated with the household, formed the fundamental unit, the nucleus of all societies. In this respect, the understanding of the analytical category 'household' was initially largely shaped by a researcher's own socialization, his or her own experience of society and sociality - and not least by their personal experience of growing up and living in a household.

In the early days of the new research field, 'households' were not the objects of the research questions but a self-evident category which was naturally assumed to have existed almost in the same manner in all (prehistoric) societies. According to the researchers' own cultural preconceptions, a dwelling was believed to be the place where a household, and thus the domicile of a family, became empirically tangible in the 
archaeological record. The common equation of 'house,' 'household', and 'family' meant that 'household archaeology practice entailed a tautology in the recognition of its analytical unit: a "house" was defined as a place where a family develops the daily activities and "family" grouped together people who inhabits in the same house' (Briz i Godino et al. 2013: 25).

Although repeatedly called into question from an early stage (Bender 1967; Yanagisako 1979), the 'household' as a concept was generally defined as a fixed package of intrinsically intertwined features that constituted everyday life-including aspects such as the dwelling, family, co-residence, private space, self-sufficiency, economic pooling, domestic activities such as production and consumption, biological reproduction, transmission, socialization, and enculturation. This entanglement of architecture, social grouping, kinship, subsistence, and biological and social reproduction was challenged by the ethnographical and historical data that demonstrated an enormous cultural variability with regard to how people organized and structured their daily lives and generated sociality; as seen from a cross-cultural perspective it becomes clear that various combinations of the features mentioned can occur. We must therefore expect to find variability, and an attempt was made by Sanjek to distinguish between five 'major household types' (Sanjek 2006: 286, with reference to Hammel and Laslett 1974). Ethnographical and historical data also demonstrate that households are not stable, ahistorical institutions, but rather pass through cycles, each stage of which may represent a particular household type, which therefore ultimately represents merely a snapshot of a particular moment in time within the household cycle (Yanagisako 1979: 168). Consequently, recent household archaeology has shown an increasing awareness of the dynamics and fluidity of households, stating that they are fundamentally unstable and subject to continual fission', and must therefore be conceptualized as 'social processes' (Souvatzi 2012).

This is not the place to retrace in detail the development of household archaeology and its shifting concepts (for an overview see Steadman 1996; Robin 2003; King 2006: 297; Goldstein 2008: 39-41; Douglass and Gonlin 2012b: 8-18; Tringham 2012). It appears important to state that as our knowledge increases and as we make more cross-cultural comparisons, our own cultural perception of the concept 'household' is fundamentally challenged, which brings into focus the immense cultural variety of the phenomenon. This is reflected in the fact that household archaeology today constitutes a very heterogeneous field with a variety of definitions for its object of research and with a remarkable plurality of theoretical perspectives and methodological approaches. Over the course of its development, the concept 'household' evolved from a seemingly self-evident, universal, and ahistorical social institution into a contested analytical category: 'household' can no longer be assumed to be a known factor. We must examine, rather, each individual case in order to ascertain whether 'household' is indeed even a useful analytical category. Ivan Briz i Godino and colleagues (2013: 26-8) thus show that for the study of hunter-gatherers 'the traditional criteria ... remain problematic or ambiguous'. They go on to say that the previously developed understanding of 'household space' and the associated localization of certain activities with either 'private' or else 'public' 
or 'communal' spaces is 'not operative' for hunter-gatherer contexts. Instead, they conclude 'that the most profitable approach for this kind of research is the recognition of the global social space with its implications for understanding the physical environment where a society develops its existence ... on the basis of production and consumption processes. Once these activities are spatially articulated, we are able to obtain an appropriate image of the social space and then to begin the study of relationships' (Briz i Godino et al. 2013: 39-40).

If this assumption was correct with regard to all hunter-gatherers it would mean that the traditional concept of household cannot be used in the analysis of Palaeolithic or Mesolithic sites-in other words for the largest part of prehistory. However, even in the study of more recent sedentary communities we may raise the question as to whether 'household' is indeed a useful analytical category. Many sites have yielded evidence of structures that cannot readily be reconciled with the traditional concept of household. Bleda Düring and Arkadiusz Marciniak (2006: 182-3) in their study of Early Neolithic sites in Central Anatolia, for instance, found no evidence of 'discrete household residences in which domestic activities were performed', but instead identified structures that overarched several houses, which they described as 'neighbourhood clusters'. This led them to conclude that the local communities had not been comprised of discrete households, but rather of neighbourhood communities (Düring and Marciniak 2006: 166). They also presumed that many of the domestic activities were not performed in the dwellings but in communal open areas (Düring and Marciniak 2006: 174). Stella Souvatzi (2012: 18) went a step further in disentangling 'house', 'household space', and 'domestic activities' and viewed 'household as a shifting location of action rather than resort[ing] to ready-made social and spatial forms'. In her opinion, household is composed of 'a social group cooperating in a sphere of social, economic, and ideological practices consisting minimally of production, distribution/consumption, transmission, and social reproduction' (Souvatzi 2012: 18). She considers household to be 'a dialectical framework for studying collective practice, as it is itself a collectivity, a coalition of individuals' (Souvatzi 2008: 39). The nature of this 'coalition of individuals' and whether it was based on phenomena such as kinship or simply on the decision to cooperate in performing certain daily activities remains unknown. Another unanswered question is the duration of these coalitions; short-term, seasonal, or even ad hoc partnerships are as conceivable as more long-term alliances. Moreover, the age and gender of the individuals involved remain unknown to us.

From an epistemological point of view, the disentanglement and dynamization of the original 'household package' based largely on Western concepts and the practical and spatial turn towards concepts, such as collective practices, social space, spatiality of everyday life, or the built environment (Robin 2002: 247-50) on the part of household archaeology, have certainly borne fruit, since they allow us to gain a much more unbiased view of 'the social construction and experience of everyday life' (Robin 2002: 245), as seen in the traces left behind in the archaeological record by 'domestic activities' (for a definition see Kovács 2013: 182) as well as 'maintenance activities' (Alarcón García and Sánchez Romero 2010) and 'daily routines'. The analysis of spatial patterns, and 
consequently the reconstruction of activity areas, are among the strengths of archaeologists, who, much like geoarchaeologists, have developed a multitude of approaches that have been successfully employed in numerous case studies (Boivin 2000; Smith, Marshall, and Parker-Pearson 2001; King 2008; Matthews 2012; Milek 2012; Kovács 2013). However, this does not actually answer the question as to which agents originally created the activity patterns captured by means of micromorphology and soil chemistry in the distribution patterns of finds, features, and archaeological layers.

\section{ACTIVITY AREAS WITH CHILDREN'S FACES?}

The renunciation of the bourgeois concept of household, however, also presents new challenges. If one disengages from the notion that households in the archaeological record are always found in the remains of dwellings that were inhabited by (nuclear) families, one is automatically faced with the question as to the protagonists within households and their roles in the social construction of everyday life. If households and houses can no longer be automatically viewed, by analogy with the bourgeois concept of family, as the domain and natural environment of women and children, and as the primary arena of domestic activity, we are forced to struggle with 'the age old problem of finding archaeological correlates for social units' (Alexander 1999: 80). Ruth Tringham (1991: 101) did not agree with a 'prehistory hanging in a cloudy nowhere-land of faceless, genderless categories' and called for researchers to 'add faces to the prehistoric households'. Although her programmatic article 'Households with Faces: The Challenge of Gender in Prehistoric Architectural Remains' (1991) deals with adding the faces of women and men, her findings also hold true for subadults. It is an enormous challenge for prehistoric archaeological research, which can be surmounted only in exceptional cases, to reconstruct the age and gender of the people who used the artefacts or moved around within a built environment without employing presuppositions (e.g. that domestic activities should generally be associated with women or that smaller children spent their time close to their mothers or near the house) and based solely on the material remains uncovered (similarly King 2006: 305). In dealing with such questions, prehistoric archaeology reaches its limits. Though we may assume that from a demographic point of view prehistory was a world of children and youths, where individuals under the age of 14 may have constituted 40-50 per cent of the population (Bocquet-Appel and Masset 1977; Bocquet-Appel 2008), it is extremely difficult to identify the traces left behind in the archaeological record by their presence and activities. However, we can be sure that 'children contribute to the archaeological record whether or not we are competent to recognize them' (Chamberlain 1997: 249).

Household archaeology has, to date, paid little attention to the possibility that children and adolescents, as agents in the construction of everyday life, significantly contributed to the formation of archaeological features linked with households or with activity areas in the broader sense. Even in gender-informed approaches that endeavour 
to make 'studies of the household more "enpeopled"' (Hendon 2006: 172), subadults are not perceived as agents whose day-to-day roles should be the object of archaeological research as much as those of women and men. As a rule, children appear only in the context of either one of two topics: the demographic composition of a community or the functions of households, specifically in socialization and in the rearing of children. The fact that adolescents possibly carried out some of the many day-to-day domestic activities is not dealt with, although researchers state that the 'division of labour by gender (and age) is a common organizational mechanism for households' (Hendon 2006: 179). Kristin De Lucia (2010: 608) took it a step further by calling on archaeologists to 'reconceptualize houses as places of children' in order to 'integrate children and their material culture ... as fundamental parts to understanding how households functioned as a whole?.

In childhood archaeology, however, the roles of subadults in households and in the construction of everyday life have not yet become one of the central research questions, although a series of theoretical and methodological approaches have been developed over the past twenty years, which have made a fundamental contribution to rendering children 'visible' in the archaeological record (Moore and Scott 1997; Sofaer Derevenski 200ob; Crawford 2009). In contrast to household archaeology, it is one of the central goals of childhood archaeology to examine children's contribution to site formation and the archaeological record. Jane Eva Baxter (2006a, $b: 3-5)$ in particular has challenged previous assumptions 'that children have a randomizing and/or distorting effect on artefact distributions that makes it virtually impossible for archaeologists to study children in behavioural contexts' and has argued the case for no longer viewing children as 'distorting factors' that 'altered the material expressions of adult behaviours', but rather as 'active members of the social unit under observation' (Baxter 2006a: 78). However, it remains a huge challenge to actually identify the activities of these members, for instance in the distribution of artefacts throughout a given settlement, nor is this likely to change to any great extent in the future.

Whilst the expertise on reading the traces left behind in the archaeological record by subadults has considerably increased thanks to childhood archaeology, the insight gained is still rather limited, both quantitatively and qualitatively. It generally refers to only a number of particular aspects and often depends on very specific, extraordinarily favourable site formation processes and preservation conditions, as seen, for example, in the case of footprints. Nevertheless, a series of works have recently been published that highlight the presence of children and youths by means of imprints of various body parts, e.g. foot and handprints in archaeological features or fingerprints on ceramic vessels, animal figurines, and human statuettes (Kamp et al. 1999; Roveland 2000; Králik, Urbanová, and Hložek 2008; Ashton 2014 et al.). Fingerprints on ceramics draw our attention to an aspect that is generally forgotten outside of childhood archaeological research: prehistoric children actually produced material culture-and this concerns not just toys, but also ceramic vessels, flint tools etc. This in turn raises the question as to how children learned or how cultural techniques and traditions were handed down and how one would distinguish between adult and child learners, for instance based on 
typical beginners' mistakes (van Berg 1996; Smith 2006; Ferguson 2008). With regard to activity areas, flint-knapping sites are of particular importance because, in some cases, we may actually assume, based on the debitage found, that this was a site where in all likelihood a child once sat down to learn how to knap flint (Johansen 1999; Grimm 2000; Shea 2006; Stapert 2007; Högberg 2008).

Aside from these finds and features-which directly point to the presence and activities of children-miniature artefacts, special shapes, and unusually small objects are also associated with children. Examples of this include a Late Bronze Age wooden sword (for which, however, an alternative interpretation as a weaving sword has also been suggested (Figure 7.2; Hafner and Harb 2008; Hafner, Harb, and Lötscher 2008)), rattles
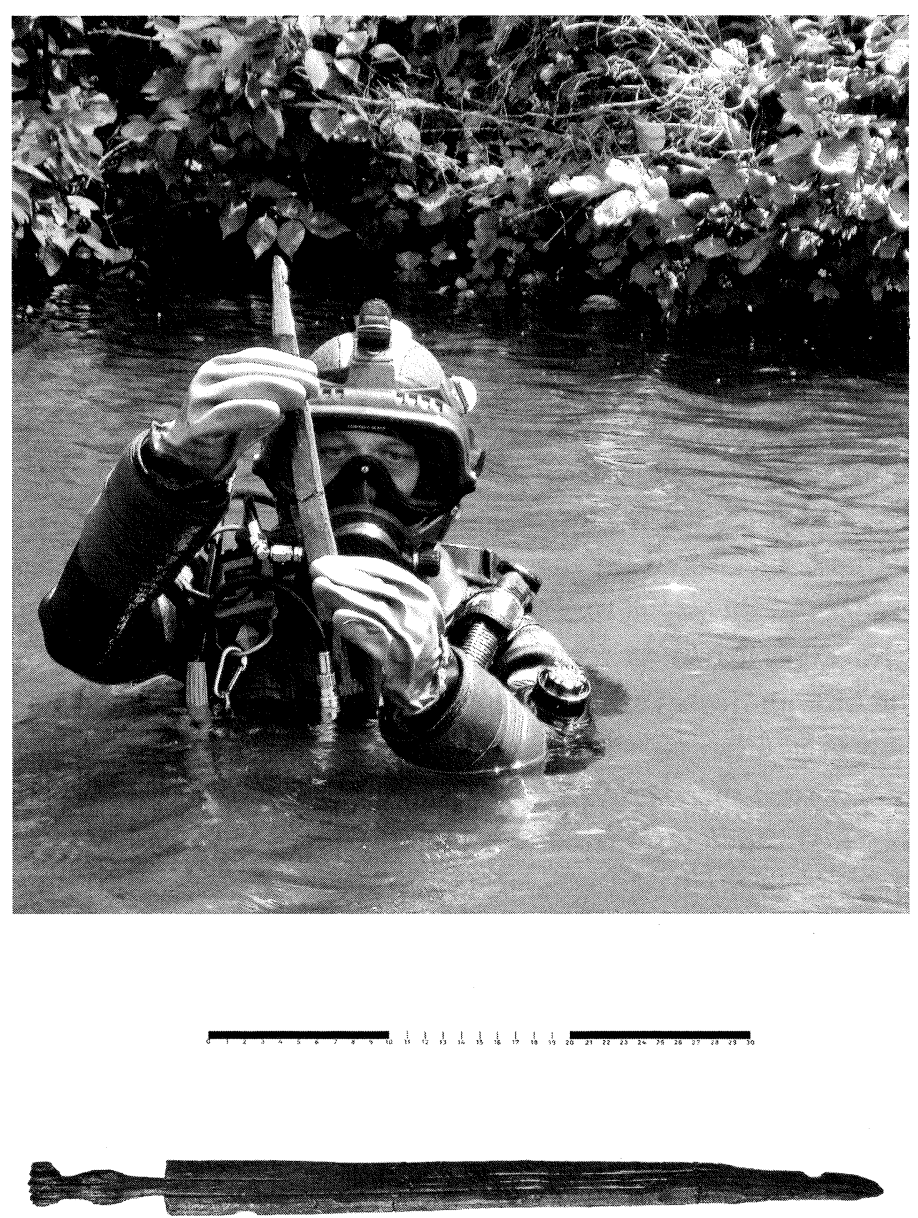

FIGURE 7.2 Wooden sword of a child or weaving sword? Miniature artefacts like this sword, found in a Late Bronze Age settlement in Lake Inkwil (Canton of Berne, Switzerland), raise the question of whether it is a toy or rather a special tool. Reproduced by permission of Kantonsarchäologie Solothurn and Archäologischer Dienst Bern (Switzerland). 


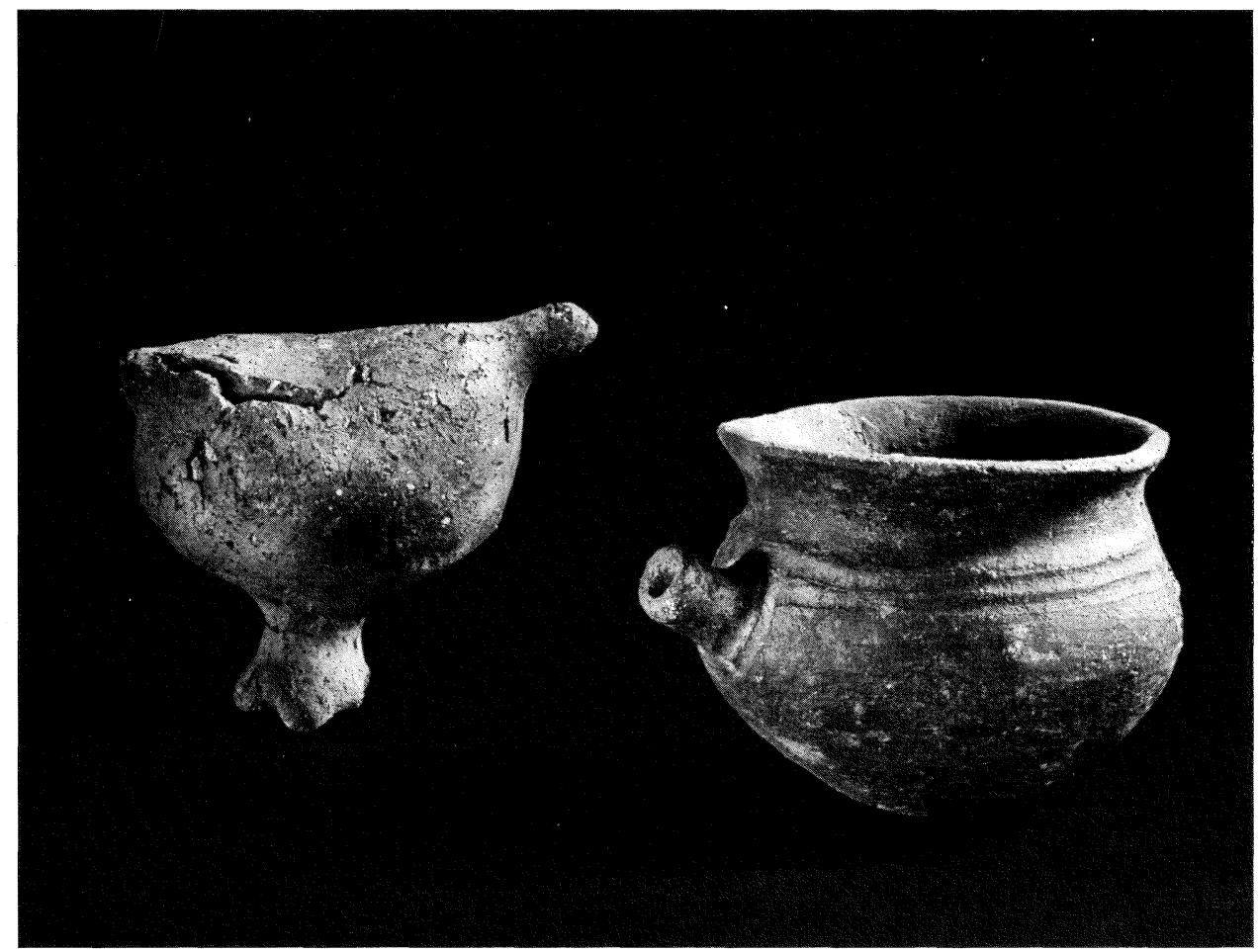

FIGURE 7.3 Special forms such as rattles and so-called ceramic feeding bottles are usually associated by archaeologists either with children or with ritual practices. On the left a rattle in the form of a bird, on the right a feeding bottle from the Late Bronze Age lakeside settlements of Mörigen (Canton of Berne, Switzerland) and Grandson-Corcelettes (Canton of Vaud, Switzerland). Reproduced by permission of Bernisches Historisches Museum (Switzerland). Photograph by S. Rebsamen.

and so-called ceramic feeding bottles (Figure 7.3), and a small handaxe, which would perfectly fit in a child's hand (Figure 7.4). Due to the lack of reliable criteria, particularly in dealing with settlement finds, it cannot be determined whether the rattles and feeding bottles were toys or children's vessels, or whether these artefacts were, rather, used in religious or ceremonial contexts. There is even a different possible explanation for the small tools: they are more often interpreted as special tools used by adults than as children's tools.

The interpretation that is chosen for such artefacts ultimately depends on the individual researchers' assessments. If they are of the opinion that prehistoric children spent most of their time playing games rather than working, they are more likely to interpret small tools as special tools for adults. As a consequence, they will also assume that material culture was generated first and foremost by adults.

In other words, whether children's activities are identified in the archaeological record is largely determined by the individual researchers' concepts of childhood. Those who associate childhood mainly with playing games will look out for objects that 


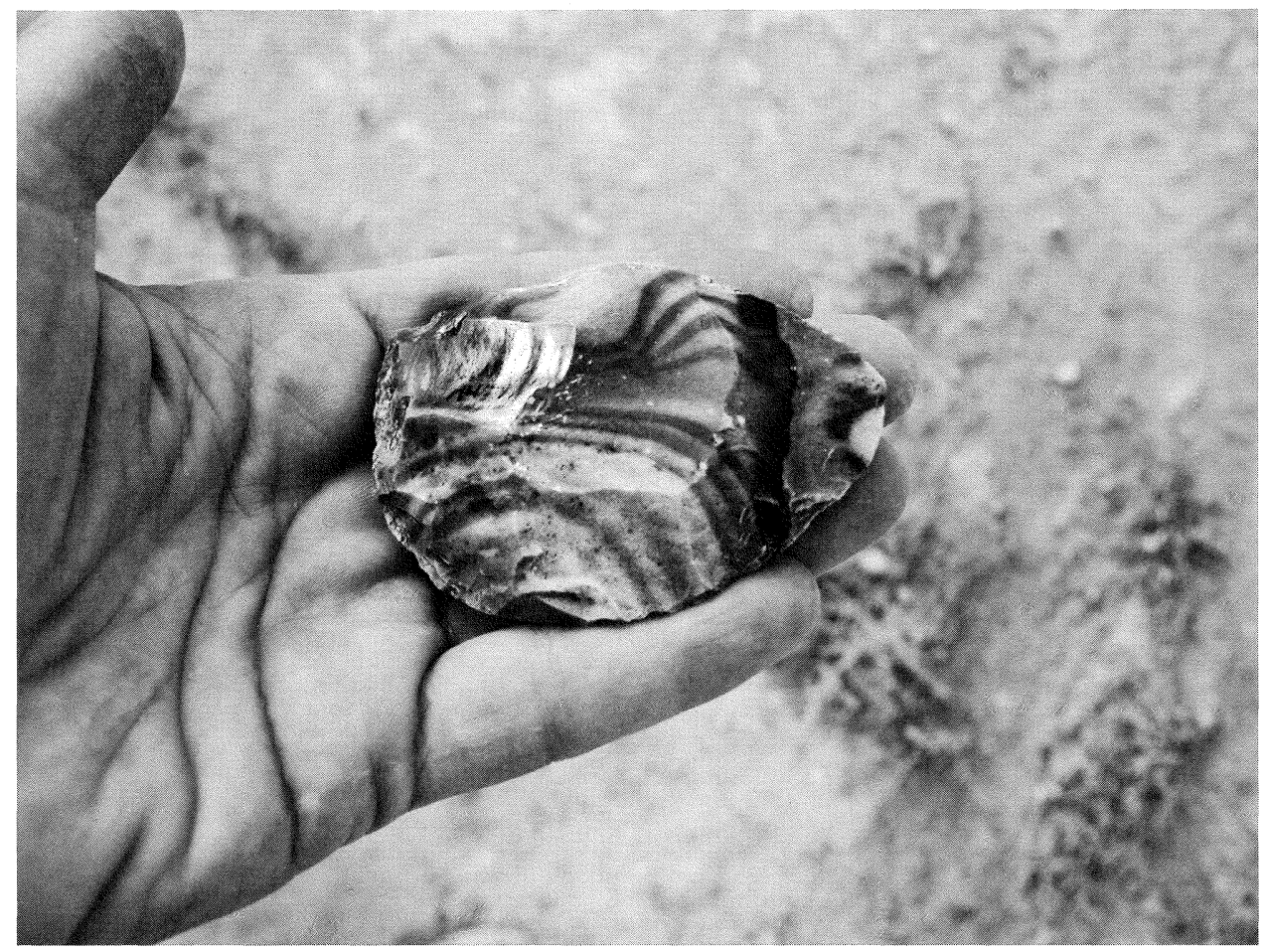

FIGURE 7.4 Small handaxe made for a child's hand or rather a special tool for adults? The handaxe is about 500,000 years old and was found in the Palaeolithic site of Nadaouiyeh Ain Askar (Syria). Reproduced by permission of Daniela Hager, Basel (Switzerland).

correspond with our present-day idea of what toys are-and they will discover that these are extremely rare among the finds left behind by most archaeological cultures and ask: where have all the children gone? Those who bear in mind the demographic conditions that probably prevailed in prehistoric times and take into account present-day hunter-gatherer and agrarian societies, will recognize that 'work' and 'play' would have seamlessly blended into each other and prehistoric children would have begun to take part in carrying out everyday domestic and subsistence activities from a very early age. Consequently, they will automatically expect a large part of the material culture to have been generated and used by subadults (for contemporary examples see Weiss 1981: 316, 1993; Bugarin 2006). This expectation generates a different view of material culture and therefore a different search pattern, in that one would think about which steps in the chaine opératoire of making a particular artefact might have been carried out, in principle, by a child of whatever age. In the case of pottery production, options would be the time-consuming task of burnishing the leather-hard surfaces, or perhaps the charging of the pottery kilns (Röder 2009: 105, 108-10); both are tasks that would not have left behind any visible fingerprints for us to identify today. Finally, it should also be borne in mind that children - as is often the case today as well-would also have used 'adult' material culture (Bugarin 2006: 14). 
These examples highlight that, despite a meticulous search and sophisticated methodological approaches, it is only rarely possible to identify activities of children and adolescents in the archaeological record. The majority of material remains do not reveal the age and gender either of those who created them or of the succession of people who went on to use them over the course of the artefacts' lifespans. The 'peopling [of] the material record of past households' (Robin 2003: 336) empirically and directly from the material remains and, based upon this, the reconstruction of the roles of subadults in households and the construction of daily life, is therefore virtually impossible. All that remains is to adapt the suggestion made by Ruth Tringham (1991: 118) with regard to an analogous problem, i.e. the question of identifying women and men: 'The solution to "adding faces" to the prehistoric households, however, lies ... in enriching the archaeologists' models and general knowledge of gender relations within household and families'. According to Tringham, this enrichment can be achieved by studying ethnographic and historical literature, which will demonstrate the rich variability of the cultural phenomenon studied. She concludes: "We do not have to "identify" this rich variability in the archaeological record but we must be aware of it. Why simplify prehistory?' (1991: 119).

\section{CHILDREN'S CONTRIBUTIONS TO DOMESTIC ACTIVITIES IN CONTEMPORARY AGRARIAN AND PASTORAL SOCIETIES}

In order to counteract the simplification of prehistory and especially of prehistoric childhoods, I would like to use this chapter to highlight children's contributions to domestic activities in contemporary agrarian and pastoral societies based on a number of social anthropological studies (for more detailed remarks see Röder 2015). The aim is to generate ideas of how to add children's faces to prehistoric households or to activity areas-in other words, how to 'reconceptualize houses as places of children' (De Lucia 2010: 608). The focus therefore is on domestic activities because they, unlike other aspects that greatly impact on the growing up of children in their primary groups-for instance class or age and gender hierarchies-have left behind traces in the archaeological records of settlements.

Studies on child labour show that it is common practice in agrarian and pastoralist societies for children to carry out certain age-appropriate tasks from an early age, i.e. from as young as three to five years old. Therefore, children often contribute to the community's subsistence even before their fifth birthday (Nieuwenhuys 1994: 13, 15-16; Panter-Brick 2000: 6-8). A large proportion of tasks performed by children are associated with domestic activities. The contribution made by children can make up as much as half of all the work performed by the members of a household (Bugarin 2006: 14 with examples). A significant part of the work is associated with childcare. A study on 
child labour in the context of subsistence farming in Zimbabwe conducted by Pamela Reynolds (1991: 66) revealed that, aside from the mothers, children between four and eight years of age are the group that spends the most time caring for children. Other domestic activities that children as young as two or three years, but definitely from the age of five, are coping with reliably in many societies are small jobs, such as carrying messages, fetching and delivering things (e.g. food for people working in the fields), running errands, lending a hand etc., cleaning, preparing food, fetching water, or gathering wood or fodder for the animals (for an overview see Liebel 2004: 81-7; Kramer 2005: 35, fig. 2.1). Moreover, children are also involved in numerous other activities including crafts, fieldwork, and animal husbandry. We may generally state that children from as young as five years old already make a significant contribution to the handling of domestic activities and the general subsistence, thereby freeing up the older children and adults to carry out more complex and physically taxing tasks.

At what stage the subadults are considered to have mastered the entire range of dayto-day tasks and to have obtained the required knowledge varies from one cultural group to the next-but compared to contemporary Western societies it occurs quite early. The ages at which subadults are considered fully-fledged workers vary between seven and 15 years (Röder 2015). The age-appropriate (self-) integration of children into the day-to-day work of their primary group, on the other hand, appears to be a crosscultural phenomenon. Any skills, competences, and knowledge are largely self-taught and children exhibit a high intrinsic motivation to observe and get involved in the tasks, rather than waiting to be instructed by adults (Polak 1998: 112 with reference to Rogoff 1990). Children want to be a part of what is going on and rarely need to be reminded of their tasks (Polak 1998: 108).

Without the contribution made by children, the workload in agrarian and pastoralist societies could not be managed. Children lighten the burden on adults whilst contributing to their own subsistence and to the productivity of the whole household (among others Nieuwenhuys 1996: 241 with further references). A very interesting study in this context was carried out by Karen Kramer (2005) in a Maya village in Mexico where the households consisted of nuclear families. Kramer examined children's consumption and production on one hand and the points in time at which they made their contributions to the economy over the course of the demographic and economic life cycle of the family on the other. The study revealed that the daily workload increases as a family grows and that the capacity of a couple is already exceeded once the household has grown to consist of four people (Kramer 2005: 145). The period between the ninth and fifteenth year of the marriage or household are the most difficult for the parents because at that stage they have several small children. From the fifteenth year of a household's life cycle onwards, the older children contribute more and more to the production whilst the parents' workload decreases. The economic contributions made by the Maya children counterbalance their consumption to a considerable degree, particularly during the phase of the family's life cycle when the economic pressure on the household is at its most intense. From a demographic point of view, this means that children by their contributions to the family's subsistence make it possible for parents to have more children 
even in phases of the family cycle during which they do not have the time and resources to support the family economically (Kramer 2005: 148-51; similarly Kaplan 1994).

It must be borne in mind that Kramer's case study dealt with a specific type of family and household (largely self-sufficient nuclear families) and that the results cannot be generalized, since the type of household also has an impact on the workload of children (Munroe, Munroe, and Shimmin 1984: 372). By operating within larger social networks, polygamous families are able to increase their economic productivity and thus-partly thanks to the cooperation of the wives-decrease the workload of each individual family member (Merten and Haller 2005: 74, 78-80; similarly Lancy 1996: 149). Georg Klute (1996: 216) pointed out that seasonal workload peak periods or temporary shortages of labour within a family can be alleviated by several households working together. Aside from the type of family or household, a child's workload also varies due to its age, the current phase in the household or family's life cycle, the size, age, and gender composition of the household, the child's position within the sequence of births, and its gender (among others Reynolds 1991: xxix; 123; Congdon Fors 2010: 19). Furthermore, the general subsistence conditions also have a great impact on children's workloads; the more difficult the conditions, the harder children's work. Temporary economic emergency situations, for instance due to crop failures, also generally lead to an increase in child labour (see e.g. Beegle, Dehejia, and Gatti 2006). A decisive factor in children's workloads is the economic situation of the households they live in; whilst poverty promotes child labour and even necessitates it, the reverse tendency also exists, so that prosperity in a household reduces the workload of its children. Finally, adolescents' workloads are also influenced by exploitative relationships within their families or primary groups, which are legitimized by intrafamilial age and gender hierarchies whilst also being associated with broader societal structures of exploitation (Folbre 1986; Nieuwenhuys 2000: 279-81, 286-90, each with further references). The fact that these aspects all have a bearing on how children grow up and on the formation of very different childhoods must also be borne in mind when studying prehistoric societies.

\section{GROWING UP BEYOND THE 'WALLED GARDEN' OF A PARENTAL HOUSEHOLD}

The prevailing opinion in present-day Western societies is that children should ideally grow up with their biological family of origin, i.e. in the care of their biological parents. However, many other societies practise other forms of growing up beyond the 'walled garden' of a parental household, which, in principle, must also be considered to have existed in prehistory. These include phenomena such as fostering, adoption, so-called autonomous children's groups, and the option of children living in different households depending on their age, or in gender and age-segregated spaces (Lane 1994; Burton, Nero, and Egan 2002; Bugarin 2006). Fostering is a particularly widespread 
phenomenon that, contrary to Western beliefs, must not be thought of as compromising the wellbeing of the child, but is seen as a desirable expansion of a child's experiential background and its learning potential as well as a chance for the child and its biological family to advance their social status. Moreover, it can make sense for many families during certain phases of their household's life cycle to take in other children (Klute 1996: 216). Conversely, other families may find it economically lucrative or, due to a shortage of resources, even necessary to send children to work in other households or to have them adopted by other families.

From a Western perspective, quite strange or even exotic are the so-called autonomous children's groups known from indigenous societies in the Andes (Liebel 2004: 95-6), from the Iatmul in Papua New Guinea (Weiss 1981, 1993), and from Tonga (Meiser 1997). These groups, which children join at a very young age-in Tonga at the age of two (Meiser 1997: 213), among the Iatmul at the age of four to five (Weiss 1993: 120) - are separate, socially recognized institutions that are quite independent of parents, within which communal processes of development and learning take place. Adults generally do not become involved in these processes and are only marginally interested in the children's activities (Meiser 1997: 217). The autonomous children's groups demonstrate that socialization is not necessarily limited to the nuclear family but can also largely take place within a peer group (Meiser 1997: 221). The groups give adolescents a high degree of self-determination and freedom to make decisions (Meiser 1997: 213). They also provide a certain degree of economic autonomy, which is based on free access to resources and means of production. This allows the children to acquire independently either the products or the raw materials to create the products and to have them at their disposal (Weiss 1993: 116). The children's economic relationships allow them to create independently close bonds with different people based on the principle of mutuality (Weiss 1993: 119). This way the children fashion their own social networks that reach beyond their families of origin. The networks increase their social security and thus their economic, social, and emotional independence from their biological families. Ute Meiser (1997) made similar observations with regard to the economic autonomy of subadults in Tongan society. With regard to the integration of children's groups into society, Meiser states that Tongan children can claim their own living environment or 'children's culture' whilst still being part of the adult world. Recognized and accepted by the adults, they make important contributions to the familial economy. Whilst in some way independent of adults, they are never independent of the group that is the basis of their material and emotional sustenance (Meiser 1997: 223).

The Western reaction to autonomous children's groups is often one of incredulous amazement and they do inspire a-sometimes virtually enthusiastic-contemplation of alternative concepts of rearing children. Western ideals of the 'right' childhood are most seriously challenged by children growing up 'on their own', i.e. left to their own devices and not under the care, supervision, and responsibility of adults, and supporting themselves economically (Panter-Brick 2000: 4-10; Veale, Taylor, and Linehan 2000: 138-9). Self-reliant living outside of a (familial) 'home' and economic autonomy stand in stark 
contrast to the normative ideas of an adequate childhood, which is ultimately always linked to an economic dependence on parents and life within a family (Panter-Brick 2000: 6). Such 'alternative' forms of growing up arouse ambivalent emotions; from a Western perspective these children appear to be either extremely pitiful or else deviant, and as a consequence the children are either viewed as victims or as delinquents (Veale, Taylor, and Linehan 2000: 138), a perception which radically differs from the subadults' own self-perception. This ambivalence is particularly obvious in the case of street children who for various reasons do not live in familial households, either because they were separated from their families by specific circumstances, such as being orphaned, war, flight, or displacement, or because they left their families voluntarily and of their own volition because living 'on the streets' seemed to them to be the better option than living 'in the bosom of the family'.

Such 'alternative' childhoods also existed in the European past (Panter-Brick 2000: 78) and must be considered to have potentially existed in prehistoric societies. Moreover, the example of the street children raises one's awareness of the fact that children-when they are forced to-can develop great competence and are able to live self-reliant lives outside of familial structures and households and under precarious circumstances without adult care and supervision.

\section{Conclusions}

From the perspective of contemporary societies, 'childhood' and 'household' are not universal, static categories but rather culturally, highly variable dimensions of social life that can be influenced by numerous factors and are thus in constant flux and everchanging. 'Childhood' and 'household' appear to be complex social processes that are entwined with each other and are characterized by changing actors. By assuming that the same high variability, complexity, dynamic, and mutual entanglement existed in prehistoric times and by viewing 'childhood' and 'household' as social processes, we find ourselves confronted with great epistemological challenges. The material traces left behind by these processes in the archaeological record are rudimentary and offer no immediate access to 'childhood' or 'household'. In this respect, the possibilities of reconstructing these intertwined processes remain quite limited, which raises the question as to whether 'household' and 'childhood', or the combination of both, are even useful and productive analytical categories. The material traces of recurring everyday practices, daily routines, and their spatial organization are easy to identify in the archaeological record. Domestic or maintenance activities, in particular, are relatively well documented at settlement sites and therefore offer the best vantage point from which to approach the question of social construction and organization, the structuring of everyday life, and the part played by subadults in these processes. Instead of examining the role of children in households, I would like to call for a study on the role played by children and adolescents in the formation of archaeologically tangible activity areas in the 
hope of gaining insight into the participation of subadults in the construction of everyday life and daily routines.

It helps to bear in mind that individuals under the age of 14 must have constituted roughly half of the prehistoric population. In other words, even if we cannot prove it based on the finds and features available, it is highly likely that subadults made a significant contribution to the formation of activity areas. The study of contemporary subsistence-based societies has shown that the early integration of subadults into daily activities is a structural necessity. This way, children take part in social life from a very young age. Their labour constitutes a central component in their daily routines and therefore their world of experience and the process of growing up. Consequently, domestic activities are an important medium of socialization, enculturation, and social and economic participation of subadults.

This approach challenges previously held viewpoints that were based on our own cultural concepts of 'childhood' and 'household'. On the other hand, it also opens up a space to develop a new thinking and ask new questions about the roles of children, adolescents, and adults in everyday life and the daily routines of prehistoric societies. Our own ideas of what 'childhood' means are broadened and 'alternative childhoods' come into view, i.e. types of growing up that are not commonplace in our own cultural environment and have therefore not yet found their way into the scope of archaeological interpretation.

The perception of children as 'actors who make important contributions to their communities' (Baxter 2006b: 6) also calls into question the dichotomy between 'children' and 'adults' and between 'childhood' and 'adulthood'. Manfred Liebel (2004: 77) states: 'Children's work provides evidence that the phase of life that we refer to as childhood is not only regarded as a still immature stage of preparation for adult life, but that it already involves important tasks for the reproduction and development of society'. A similar opinion is voiced by Michael Bourdillon (2006: 1207): 'Children are not merely potential adults or citizens, to be moulded into the roles determined by adults: children are already participants in society. Their work is an element of this participation'. Contemporary surveys involving children have shown that they perceive their labour as carrying with it a series of positive aspects: they feel empowered and gain in confidence and self-assurance. They sense that work gives them social weight and that their labour is indispensable for both their families and society at large. They find joy and learn to hold their ground and to become more independent (Liebel 2004: 2).

The question as to whether we may assume that prehistoric children experienced the same sense of self must remain unanswered. We can, however, definitely presume that prehistoric children experienced a higher level of agency and took on more responsibilities, and thus had a much greater impact on everyday life, the economy, and the historical development than is commonly believed. Children were not just bystanders in an adult world, as is the stereotype depicted in archaeological images (Röder 2008: 69-71), but principal actors in a world in which subadults under the age of 14 may have constituted almost half of the population. Their participation in the routines of everyday life constituted a considerable component in their world of experience and the process of 
growing up, whilst at the same time impacting on the everyday lives of the other age groups to an extent that we can hardly imagine today.

\section{Notes}

1. Spencer-Wood (1999: 170) highlights the fact that bourgeois gender and family ideology 'wasn't even universally espoused or practised by nineteenth-century Americans or Europeans' and was even partially rejected.

2. For an attempt at dividing subadult children (o-12 years of age) into four 'serial categories' based on physical, mental, and social development stages, see Fahlander 2011: 17-19.

3. An interesting study in this context was carried out between 2002 and 2004 in Los Angeles. It revealed that children's participation in household chores can generally be classified as minimal (Klein, Graesch, and Izquierdo 2009: 106).

4. Basic works and more recent overviews include: Bender 1967; Hammel and Laslett 1974; Yanagisako 1979; Wilk and Rathje 1982; Netting, Wilk, and Arnould 1984; Tringham 1991, 2012; Blanton 1994; Hendon 1996, 2006; Allison 1999; Robin 2002, 2003; Robin and Brumfiel 2008; Souvatzi 2008, 2012; Nash 2009; Douglass and Gonlin 2012a, $b$; Parker and Foster 2012; Madella et al. 2013.

\section{REFERENCES}

Alarcón García, E. and Sánchez Romero, M. (2010). 'Maintenance Activities as a Category for Analysing Prehistoric Societies', in L. H. Dommasnes, T. Hjørungdal, S. Montón-Subías, M. Sánchez Romero, and N. L. Wicker (eds), Situating Gender in European Archaeologies. Budapest: Archaeolingua Alapítvány, 261-82.

Alexander, R. T. (1999). 'Mesoamerican House Lots and Archaeological Site Structure: Problems of Inference in Yaxcaba, Yucatan, Mexico, 1750-1847', in P. M. Allison (ed.), The Archaeology of Household Activities. London: Routledge, 78-10o.

Allison, P. M. (ed.) (1999). The Archaeology of Household Activities. London: Routledge.

Ashton, N., Lewis, S. G., De Groote, I., Duffy, S. M., Bates, M., Bates, R., Hoare, P., Lewis, M., Parfitt, S. A., Peglar, S., and Williams, C. (2014). 'Hominin Footprints from Early Pleistocene Deposits at Happisburgh, UK'. PLoS One, 9/2: e88329. doi:10.1371/journal.pone.0o88329 (last accessed 09/02/2014).

Baxter, J. E. (2006a). 'Making Space for Children in Archaeological Interpretations'. Archeological Papers of the American Anthropological Association, 15: 77-88.

Baxter, J. E. (2006b). 'Introduction: The Archaeology of Childhood in Context'. Archeological Papers of the American Anthropological Association, 15: 1-9.

Beegle, K., Dehejia R. H., and Gatti, R. (2006). 'Child Labor and Agricultural Shocks'. Journal of Development Economics, 81: 80-96.

Bender, D. R. (1967). 'A Refinement of the Concept of Household: Families, Co-residence, and Domestic Functions'. American Anthropologist, 69/5: 493-504.

Blanton, R. E. (1994). Houses and Households: A Comparative Study. Interdisciplinary Contributions to Archaeology. New York, NY: Plenum Press.

Bocquet-Appel, J-P. (2008). La paléodémographie. 99.99\% de l'histoire démographique des hommes. Paris: Errance. 
Bocquet-Appel, J-P. and Masset, C. (1977). 'Estimateurs en Paléodémographie’. L'Homme, 17/ 4: 65-90.

Boivin, N. (2000). 'Life Rhythms and Floor Sequences: Excavating Time in Rural Rajasthan and Neolithic Catalhoyuk'. World Archaeology, 31/3:367-88.

Bourdillon, M. (2006). 'Children and Work: A Review of Current Literature and Debates'. Development and Change, 37/6: 1201-26.

Briz i Godino, I., Zurro, D., Álvarez, M., and Vila, A. (2013). 'The Integrity of Social Space: Hunter-Gatherers at the End of the World', in M. Madella, G. Kovács, B. KulcsarneBerzsenyi, and I. Briz i Godino (eds), The Archaeology of Household. Oxford: Oxbow, 23-44.

Brumfiel, E. M. and Robin, C. (2008). 'Gender, Households, and Society: An Introduction'. Archeological Papers of the American Anthropological Association, 18: 1-16.

Bugarin, F. T. (2006). 'Constructing an Archaeology of Children: Studying Children and Child Material Culture from the African Past'. Archeological Papers of the American Anthropological Association, 15: 13-26.

Burton, M. L., Nero, K. L., and Egan, J. A. (2002). 'The Circulation of Children Through Households in Yap and Kosrae.' Ethos, 29/3: 329-56.

Chamberlain, A. T. (1997). 'Commentary: Missing Stages of Life-Towards the Perception of Children in Archaeology', in J. Moore and E. Scott (eds), Invisible People and Processes: Writing Gender and Childhood into European Archaeology. London: Leicester University Press, 248-50.

Congdon Fors, H. (2010). 'Child Labour: A Review of Recent Theory and Evidence with Policy Implications'. Journal of Economic Surveys, 26/4: 570-93.

Crawford, S. (2009). 'The Archaeology of Play Things: Theorising a Toy Stage in the "Biography" of Objects'. Childhood in the Past, 2: 55-70.

De Lucia, K. (2010). 'A Child's House. Social Memory, Identity, and the Construction of Childhood in Early Postclassic Mexican Households'. American Anthropologist, 112/4: 607-24.

Douglass, J. G. and Gonlin, N. (eds) (2012a). Ancient Households of the Americas: Conceptualizing What Households Do. Boulder, CO: University Press of Colorado.

Douglass, J. G. and Gonlin, N. (2012b). 'The Household as Analytical Unit. Case Studies from the Americas', in J. G. Douglass and N. Gonlin (eds), Ancient Households of the Americas: Conceptualizing What Households Do. Boulder, CO: University Press of Colorado, 1-44.

Düring, B. S. and Marciniak, A. (2006). 'Households and Communities in the Central Anatolian Neolithic'. Archaeological Dialogues, 12/2: 165-87.

Fahlander, F. (2011). 'Subadult or Subaltern? Children as Serial Categories', in M. Lally and A. Moore (eds), (Re)Thinking the Little Ancestor: New Perspectives on the Archaeology of Infancy and Childhood. British Archaeological Reports International Series 2271. Oxford: Archaeopress, 14-23.

Ferguson, J. R. (2008). 'The When, Where, and How of Novices in Craft Production'. Journal of Archaeological Method and Theory, 15/1: 51-67.

Folbre, N. (1986). 'Hearts and Spades: Paradigms of Household Economics'. World Development, 14/2: 245-55.

Goldstein, R. C. (2008). 'Hearths, Grinding Stones, and Households: Rethinking Domestic Economy in the Andes'. Archeological Papers of the American Anthropological Association, 18: $37-48$.

Grimm, L. (2000). 'Apprentice Flintknapping: Relating Material Culture and Social Practice in the Upper Palaeolithic', in J. Sofaer Derevenski (ed.), Children and Material Culture. London: Routledge, 53-71. 
Hafner, A. and Harb, P. (2008). 'Inkwil BE/Bolken SO, Inkwilersee. Prähistorische Siedlungsreste.' Archäologie Bern: Jahrbuch des Archäologischen Dienstes des Kantons Bern 2008 = Archéologie bernoise: annuaire du Service archéologique du canton de Berne 2008, 56-9.

Hafner, A., Harb, P., and Lötscher, C. (2008). 'Neues von den Pfahlbauern am Inkwilersee-die Tauchaktion 2007'. Archäologie und Denkmalpflege im Kanton Solothurn, 13: 25-9.

Hammel, E. A. (1984). 'On the ${ }^{\star \star \star}$ of Studying Household Form and Function', in R. M. Netting, R. R. Wilk, and E. J. Arnould (eds), Households: Comparative and Historical Studies of the Domestic Group. Berkeley, CA: University of California Press, 29-43.

Hammel, E. A. and Laslett, P. (1974). 'Comparing Household Structure Over Time and Between Cultures'. Comparative Studies in Society and History, 16: 73-109.

Hendon, J. A. (1996). 'Archaeological Approaches to the Organization of Domestic Labor: Household Practice and Domestic Relations'. Annual Review of Anthropology, 25: 45-61.

Hendon, J. A. (2006). 'The Engendered Household', in S. Milledge Nelson (ed.), Handbook of Gender in Archaeology. Lanham, MD: Altamira Press, 171-98.

Hobbs, S., McKechnie, J., and Lavalette, M. (1999). Child Labor: A World History Companion. Santa Barbara, CA: ABC-CLIO.

Högberg, A. (2008). 'Playing with Flint: Tracing a Child's Imitation of Adult Work in a Lithic Assemblage'. Journal of Archaeological Method and Theory, 15/1: 112-31.

Hug, B. (2007). Babyjahre anderswo. Theorie und transkultureller Vergleich der frühen Kindheiten bei den Gusii, den!Kung San und den Iatmül. Studien zur Ethnopsychologie und zur Ethnopsychoanalyse 8. Wien: Lit Verlag.

Hug, B. (2008). 'Childhood: An Ethno-Psychological Approach', in L. H. Dommasnes and M. Wrigglesworth (eds), Children, Identity and the Past. Newcastle: Cambridge Scholars Publishing, 83-95.

Jenks, C. (1996). Childhood. London: Routledge.

Johansen, L. (1999). 'Refitting Analysis of the Hamburgian Site at Oldeholtwolde (NL): Identifying Individual Knappers'. Quartär, 49/50: 145-6.

Kamp, K. A. (2006). 'Dominant Discourses; Lived Experiences: Studying the Archaeology of Children and Childhood'. Archeological Papers of the American Anthropological Association, 15: 115-22.

Kamp, K. A., Timmerman, N., Lind, G., Graybill, J., and Natowsky, I. (1999). 'Discovering Childhood: Using Fingerprints to Find Children in the Archaeological Record'. American Antiquity, 64/2: 309-15.

Kaplan, H. (1994). 'Evolutionary and Wealth Flows Theories of Fertility: Empirical Tests and New Models'. Population and Development Review, 20/4: 753-91.

King, J. A. (2006). 'Household Archaeology, Identities and Biographies', in D. Hicks and M. C. Beaudry (eds), The Cambridge Companion to Historical Archaeology. Cambridge: Cambridge University Press, 293-313.

King, S. M. (2008). 'The Spatial Organization of Food Sharing in Early Postclassic Households: an Application of Soil Chemistry in Ancient Oaxaca, Mexico'. Journal of Archaeological Science, 35/5:1224-39.

Klein, W., Graesch, A. P., and Izquierdo, C. (2009). 'Children and Chores: A Mixed-Methods Study of Children's Household Work in Los Angeles Families'. Anthropology of Work Review, 30/3: 98-109.

Klute, G. (1996). 'Kinderarbeit bei Nomaden', in K. Beck and G. Spittler (eds), Arbeit in Afrika. Hamburg: Lit Verlag, 209-23. 
Kovács, G. (2013). 'Soil Micromorphology of the Household at Százhalombatta-Földvár Bronze Age Tell Settlement, Hungary', in M. Madella, G. Kovács, B. Kulcsarne-Berzsenyi, and I. Briz i Godino (eds), The Archaeology of Household. Oxford: Oxbow, 179-216.

Králík, M., Urbanová, P., and Hložek, M. (2008). 'Finger, Hand and Foot Imprints: The Evidence of Children on Archaeological Artefacts', in L. H. Dommasnes and M. Wrigglesworth (eds), Children, Identity and the Past. Newcastle: Cambridge Scholars Publishing, 1-15.

Kramer, K. L. (2005). Maya Children. Helpers at the Farm. Cambridge, MA: Harvard University Press.

Lancy, D. F. (1996). Playing on the Mother-ground: Cultural Routines for Children's Development. New York, NY: Guilford Press.

Lane, P. J. (1994). 'The Temporal Structuring of Settlement Space among the Dogon of Mali: An Ethnoarchaeological Study', in M. Parker-Pearson and C. Richards (eds), Architecture and Order. Approaches to Social Space. London: Routledge, 196-216.

Lawrence, S. (1999). 'Towards a Feminist Archaeology of Households: Gender and Household Structure on the Australian Goldfields', in P. M. Allison (ed.), The Archaeology of Household Activities. London: Routledge, 121-41.

Leach, E. (1999). 'Discussion: Comments from a Classicist', in P. M. Allison (ed.), The Archaeology of Household Activities. London: Routledge, 190-7.

Liebel, M. (2004). A Will of Their Own: Cross-Cultural Perspectives on Working Children. London: Zed Books.

Madella, M., Kovács, G., Kulcsarne-Berzsenyi, B., and Briz i Godino, I. (eds) (2013). The Archaeology of Household. Oxford: Oxbow.

Matthews, W. (2012). 'Defining Households: Micro-Contextual Analysis of Early Neolithic Households in the Zagros, Iran', in B. J. Parker and C. P. Foster (eds), New Perspectives on Household Archaeology. Winona Lake, IN: Eisenbrauns, 183-215.

Meiser, U. (1997). 'Spiel, Kreativität und Gruppe: Die Institution der "horizontalen" Gruppen in der sozialen und emotionalen Entwicklung tonganischer Kinder', in E. Renner, S. Riemann, I. K. Schneider, and Th. Trautmann (eds), Spiele der Kinder. Interdisziplinäre Annäherungen. Weinheim: Deutscher Studien Verlag, 207-24.

Merten, S. and Haller, T. (2005). 'Polygamy and Livestock: Security during the 2002 Drought in an Ila Chiefdom in Zambia', in A. Mayor, C. Roth, and Y. Droz (eds), Sécurité sociale et développement. Soziale Sicherheit und Entwicklung. Münster: Lit Verlag, 69-90.

Milek, K. B. (2012). 'Floor Formation Processes and the Interpretation of Site Activity Areas: An Ethnoarchaeological Study of Turf Buildings at Thverá, northeast Iceland'. Journal of Anthropological Archaeology, 31/2: 119-37.

Moore, J. and E. Scott (eds) (1997). Invisible People and Processes: Writing Gender and Childhood into European Archaeology. London: Leicester University Press.

Munroe, R. H., Munroe, R. L., and Shimmin, H. S. (1984). 'Children's Work in Four Cultures: Determinants and Consequences'. American Anthropologist, New Series, 86/ 2:369-79.

Nash, D. J. (2009). 'Household Archaeology in the Andes'. Journal of Archaeological Research, 17/3: 205-61.

Netting, R. M., Wilk, R. R., and Arnould, E. J. (eds) (1984). Households: Comparative and Historical Studies of the Domestic Group. Berkeley, CA: University of California Press.

Nieuwenhuys, O. (1994). Children's Lifeworlds: Gender, Welfare and Labour in the Developing World. London: Routledge. 
Nieuwenhuys, O. (1996). 'The Paradox of Child Labor and Anthropology'. Annual Review of Anthropology, 25: 237-51.

Nieuwenhuys, O. (2000). 'The Household Economy and the Commercial Exploitation of Children's Work: The Case of Kerala, in B. Schlemmer (ed.), The Exploited Child. London: Zed Books, 278-91.

Panter-Brick, C. (200o). 'Nobody's Children? A Reconsideration of Child Abandonment', in C. Panter-Brick and M. T. Smith (eds), Abandoned Children. Cambridge: Cambridge University Press, 1-26.

Parker, B. J. and Foster, C. P. (2012). New Perspectives on Household Archaeology. Winona Lake, IN: Eisenbrauns.

Parker-Pearson, M. and Richards, C. (1994). 'Ordering the World: Perceptions of Architecture, Space and Time', in M. Parker-Pearson and C. Richards (eds), Architecture and Order: Approaches to Social Space. London: Routledge, 1-37.

Polak, B. (1998). 'Wie Bamana Kinder Feldarbeit lernen', in H. Schmidt and A. Wirz (eds), Afrika und das Andere. Alterität und Innovation. Schriften der Vereinigung von Afrikanisten in Deutschland 17. Hamburg: Lit Verlag, 103-14.

Reynolds, P. (1991). Dance, Civet Cat. Child Labour in the Zambezi Valley. Harare: Baobab.

Robin, C. (2002). 'Outside of Houses. The Practices of Everyday Life at Chan Nòohol, Belize'. Journal of Social Archaeology, 2/2: 245-68.

Robin, C. (2003). 'New Directions in Classic Maya Household Archaeology'. Journal of Archaeological Research, 11/4:307-56.

Robin, C. and Brumfiel, E. M. (eds) (2008). Gender, Households, and Society: Unraveling the Threads of the Past and the Present. Archaeological Papers of the American Anthropological Association 18. Malden, MA: Blackwell.

Röder, B. (2008). 'Archaeological Childhood Research as Interdisciplinary Analysis', in L. H. Dommasnes and M. Wrigglesworth (eds), Children, Identity and the Past. Newcastle: Cambridge Scholars Publishing, 68-82.

Röder, B. (2009). 'Töpfernde Hausfrauen, Vollerwerbstöpfer und Puppengeschirr formende Kinder? Soziale Dimensionen urgeschichtlicher Keramikherstellung, in P. Stockhammer (ed.), Keramik jenseits von Chronologie: Beiträge der Arbeitsgemeinschaft 'Theorie in der Archäologie’ bei der Tagung des West- und Süddeutschen Verbandes für Altertumsforschung e.V. in Xanten, 7.-8. Juni 20o6. Rahden: Verlag Marie Leidorf, 93-116.

Röder, B. (2013). 'Urmenschliche Bürger-bürgerliche Urmenschen. Zur Archaisierung des bürgerlichen Geschlechter- und Familienmodells über die Urgeschichte, in D. Grisard, U. Jäger, and T. König (eds), Verschieden sein. Nachdenken über Geschlecht und Differenz. Sulzbach: Ulrike Helmer Verlag, 243-56.

Röder, B. (2015). 'Kinderarbeit heute: Perspektiven für die Ur- und Frühgeschichte', in R. Kory (ed.) with the collaboration of R. Masanz, Lebenswelten von Kindern und Frauen in der Vormoderne. Archäologische und Anthropologische Forschungen in memoriam Brigitte Lohrke. PAST-Paläowissenschaftliche Studien 4. Berlin: Curach Bhán, 275-98.

Rogoff, B. (1990). Apprenticeship in Thinking: Cognitive Development in Social Context. New York, NY: Oxford University Press.

Roveland, B. (2000). 'Footprints in the Clay: Upper Paleolithic Children in Ritual and Secular Contexts', in J. Sofaer Derevenski (ed.), Children and Material Culture. London: Routledge, 29-38.

Sanjek, R. (2006). 'Household', in A. Barnard and J. Spencer (eds), Encyclopedia of Social and Cultural Anthropology. London: Routledge, 285-8. 
Schwartzman, H. B. (2006). 'Materializing Children: Challenges for the Archaeology of Childhood'. Archeological Papers of the American Anthropological Association, 15: 123-31.

Shea, J. J. (2006). 'Child's Play: Reflections on the Invisibility of Children in the Paleolithic Record'. Evolutionary Anthropology, 15/6: 212-16.

Smith, H., Marshall, P., and Parker-Pearson, M. (2001). 'Reconstructing House Activity Areas', in U. Albarella (ed.), Environmental Archaeology: Meaning and Purpose. Dordrecht: Kluwer Academic Publishers, 249-70.

Smith, P. E. (2006). 'Children and Ceramic Innovation: A Study in the Archaeology of Children'. Archeological Papers of the American Anthropological Association, 15: 65-76.

Sofaer Derevenski, J. (2000a). 'Rings of Life: The Role of Early Metalwork in Mediating the Gendered Life Course.' World Archaeology, 31/3: 389-406.

Sofaer Derevenski, J. (ed.) (200ob). Children and Material Culture. London: Routledge.

Souvatzi, S. G. (2008). A Social Archaeology of Households in Neolithic Greece: An Anthropological Approach. Cambridge: Cambridge University Press.

Souvatzi, S. G. (2012). 'Between the Individual and the Collective: Household as a Social Process in Neolithic Greece, in B. J. Parker and C. P. Foster (eds), New Perspectives on Household Archaeology. Winona Lake, IN: Eisenbrauns, 15-43.

Spencer-Wood, S. M. (1999). 'The World their Household: Changing Meanings of the Domestic Sphere in the Nineteenth Century', in P. M. Allison (ed.), The Archaeology of Household Activities. London: Routledge, 162-89.

Stapert, D. (2007). 'Neanderthal Children and their Flints'. PalArch's Journal of Archaeology of Northwest Europe, 1/2:16-38.

Steadman, S. R. (1996). 'Recent Research in the Archaeology of Architecture: Beyond the Foundations'. Journal of Archaeological Research, 4/1: 51-93.

Stoodley, N. (2000). 'From the Cradle to the Grave: Age Organization and the Early AngloSaxon Burial Rite'. World Archaeology, 31/3: 456-72.

Thomas, K. (2006). 'The "Nature" of Childhood: Ethnography as a Tool in Approaching Children in Archaeology'. Archeological Papers of the American Anthropological Association, 15: 41-50.

Tringham, R. E. (1991). 'Households with Faces: the Challenge of Gender in Prehistoric Architectural Remains', in J. M. Gero and M. W. Conkey (eds), Engendering Archaeology. Women and Prehistory. Oxford: Basil Blackwell, 93-131.

Tringham, R. E. (2012). 'Households through a Digital Lens', in B. J. Parker and C. P. Foster (eds), New Perspectives on Household Archaeology. Winona Lake, IN: Eisenbrauns, $81-120$.

Van Berg, P-L. (1996). 'Gauches, joueurs et apprentis: production des marges dans la céramique rubanée occidentale', in P. Duhamel (ed.), La Bourgogne entre les bassins rhénan, rhodanien et parisien: carrefour ou frontière?: Actes du XVIIlème colloque interrégional sur le Néolithique, Dijon, 25-27 Octobre 1991. Dijon: Revue archéologique de l'Est, supplément 14, 29-53.

Veale, A., Taylor, M., and Linehan, C. (2000). 'Psychological perspectives of "abandoned" and "abandoning" street children', in C. Panter-Brick and M. T. Smith (eds), Abandoned Children. Cambridge: Cambridge University Press, 131-45.

Weiss, F. (1981). Kinder schildern ihren Alltag: Die Stellung des Kindes im ökonomischen System einer Dorfgemeinschaft in Papua New Guinea (Palimbei, Iatmul, Mittelsepik). Basler Beiträge zur Ethnologie 21. Basel: Ethnologisches Seminar der Universität und Museum für Völkerkunde. 
Weiss, F. (1993). 'Von der Schwierigkeit über Kinder zu forschen. Die Iatmul in PapuaNeuguinea', in M.-J. van de Loo and M. Reinhart (eds), Kinder: Ethnologische Forschungen in fünf Kontinenten. München: Trickster, 96-153.

Wilk, R. R. and Rathje, W. L. (1982). 'Household Archaeology'. American Behavioral Scientist, 25/6: 617-39.

Yanagisako, S. J. (1979). 'Family and Household: The Analysis of Domestic Groups'. Annual Review of Anthropology, 8: 161-205. 